\section{Analisis Keterkaitan Produksi Kunyit di Indonesia dan Faktor-Faktor yang Mempengaruhinya}

\author{
Analysis of the Relationship between Turmeric Production in Indonesia and the Affecting Factors
}

\author{
Nurul Husniyati Listyana* \\ Balai Besar Penelitian dan Pengembangan Tanaman Obat dan Obat Tradisional Tawangmangu \\ Corresponding author: nurul.haydar@gmail.com
}

\begin{abstract}
This study aims to analyze the relationship between turmeric production and the factors that influence it. The variables used in this study include production, export, import, inflation, land area, and exchange rate. This research is a descriptive research. The data in this study are data obtained from the Central Bureau of Statistics, Ministry of Agriculture, Ministry of Trade and Bank Indonesia. Research data were analyzed using regression analysis. The data used are secondary data for a period of 15 years namely 2002-2016. The results showed that the variables of export, import, inflation, land area and exchange rate together significantly influence the production of turmeric. Partially, the export, inflation and land area variables significantly influence the production of turmeric. While the import and exchange rate variables have no significant effect on turmeric production.
\end{abstract}

Keywords: turmeric production, traditional medicine, turmeric export, turmeric import

Cite this as: Listyana, N. H. 2018. Analisis Keterkaitan Produksi Kunyit di Indonesia dan Faktor-Faktor yang Mempengaruhinya. Caraka Tani: Journal of Sustainable Agriculture. 33(2), 106-114. doi: http://dx.doi.org/10.20961/carakatani.v33i2.20782

\section{PENDAHULUAN}

Indonesia merupakan negara yang mempunyai kekayaan keragaman hayati nomor 2 terbesar di dunia setelah Brazil. Diantaranya adalah biofarmaka yang bermanfaat dalam aspek medis (kesehatan) secara langsung maupun tidak langsung. Sekarang ini ada kecenderungan masyarakat untuk mengkonsumsi obat tradisional, karena adanya perubahan gaya hidup back to nature dan mahalnya obat-obatan modern yang membuat permintaan tanaman obat semakin tinggi, tidak hanya di Indonesia tetapi juga dunia (Salim dan Munadi, 2017).

Kunyit merupakan tanaman obat yang banyak dibutuhkan oleh industri obat tradisional. Kunyit merupakan tanaman dari golongan Zingiberaceae berupa semak dan bersifat tahunan (perennial) yang tersebar di seluruh daerah tropis (Labban,
2014). Tanaman kunyit tumbuh subur dan liar di sekitar hutan atau bekas kebun. Tanaman ini banyak dibudidayakan di Asia Selatan khususnya di India, Cina Selatan, Taiwan, Indonesia (Jawa), dan Filipina (Ahmad et al., 2010). Sifat-sifat kimia tanah tidak berpengaruh terhadap kadar kurkumin kunyit, sehingga kunyit dapat ditanam pada jenis tanah apapun (Sholehah et al., 2016). Menurut Dinas Pertanian Daerah Istimewa Yogyakarta (no date), di pulau Jawa, kunyit banyak digunakan sebagai jamu karena berkhasiat menyejukkan, membersihkan, mengeringkan, menghilangkan gatal, dan menyembuhkan kesemutan. Manfaat utama tanaman kunyit antara lain sebagai bahan obat tradisional, bahan baku industri jamu dan kosmetik dan bahan bumbu masak (Hartati, 2013). Kunyit dimasukkan dalam daftar prioritas World Health Organization (WHO) sebagai tanaman obat yang paling banyak

\footnotetext{
* Received for publication May 2, 2018

Accepted after corrections September 17, 2018
} 
dipakai di berbagai negara dan sering disebut dalam buku-buku farmasi serta ditulis dalam resep tradisional maupun resep resmi (Hartati, 2013).

Selain itu, kunyit juga mempunyai efek anti peradangan, antivirus, antibakteri, antioksidan, aktivitas nematisida dan sebagainya. Komponen utama yang berfungsi sebagai pengobatan adalah kurkumin (Simanjuntak, 2012). Kunyit juga terbukti sebagai anti-inflamasi, antioksidan, antimutagenik, antidiabetes, antibakteri, hepatoprotektif, ekspektoran dan aktivitas farmakologi antikanker (Krup et al., 2013). Kandungan senyawa kimia dalam kunyit yaitu kurkumin (diferuloylmethane; komponen utama berwarna kuning), demetoksikurkumin, dan bisdemetoksikurkumin, serta minyak atsiri (turmeron, atlanton, dan zingiberen), gula, protein, dan resin (Jurenka, 2009).

Produksi kunyit Indonesia tahun 2016 sebesar 107.770.473 ton, didominasi dari 5 propinsi yaitu Jawa Timur, Jawa Tengah, Jawa Barat, Bengkulu dan Kalimantan Selatan dengan masing-masing produksi sebesar $33.326 .049 \mathrm{~kg}, 27.632 .177 \mathrm{~kg}$, $9.758 .569 \mathrm{~kg}, 4.535 .612 \mathrm{~kg}$ dan $4.126 .455 \mathrm{~kg}$. Kelima propinsi tersebut memberikan kontribusi masing-masing sebesar 30,92\%, 25,64\%, 9,05\%, $4,21 \%$ dan $3,83 \%$ terhadap total produksi nasional. Luas lahan produksi kunyit kelima propinsi tersebut yaitu masing-masing 22.534 .808 $\mathrm{m}^{2}, 11.196 .753 \mathrm{~m}^{2}, 4.753 .033 \mathrm{~m}^{2}, 1.001 .035 \mathrm{~m}^{2}$ dan 2.212.266 $\mathrm{m}^{2}$ (BPS, 2016). Di pasar dunia, India merupakan produsen, konsumen, dan eksportir kunyit terbesar di dunia. India diperkirakan menyumbang sekitar $80 \%$ total produksi kunyit didunia dan $60 \%$ total ekspor kunyit di dunia (Nuroho dan Ningsih, 2017).

Berdasarkan data BPS, nilai produksi kunyit selama kurun waktu 2002-2016 mengalami pasang surut. Produksi tertinggi terjadi pada tahun 2009 yaitu sebesar $124.000 .000 \mathrm{~kg}$ sedangkan produksi terendah terjadi pada tahun 2014 yaitu sebesar $7.355 .584 \mathrm{~kg}$. Selain untuk memenuhi kebutuhan industri di dalam negeri produksi kunyit di Indonesia sebagian juga digunakan untuk mencukupi kebutuhan industri luar negeri. Ekspor kunyit terbesar yaitu ke negara India dengan volume ekspor sebesar 6.091 ton BPS, 2016). Selain mampu melakukan ekspor, ternyata Indonesia juga masih melakukan impor kunyit dari luar negeri di waktu yang bersamaan. Dengan demikian perlu dilakukan analisis keterkaitan antara produksi dan nilai ekspor impor kunyit selama kurun waktu 2002-2016. Tujuan dari penelitian ini adalah untuk mengetahui pengaruh antara produksi kunyit di Indonesia dan faktorfaktor yang mempengaruhinya.

\section{METODE PENELITIAN}

Penelitian ini merupakan penelitian deskriptif. Penelitian deskriptif bertujuan untuk memberikan gambaran tentang suatu gejala tertentu. Salah satu yang termasuk dalam penelitian deskriptif yaitu penelitian yang mencari hubungan antara dua variabel atau lebih (Sukandarrumidi, 2012). Data penelitian berupa data sekunder yang diperoleh dari Badan Pusat Statistik, Kementerian Pertanian, Kementerian Perdagangan dan Bank Indonesia. Data yang digunakan berupa data selama kurun waktu 15 tahun terakhir, yaitu tahun 2002-2016. Faktor-faktor yang digunakan dalam analisis yaitu jumlah ekspor kunyit, jumlah impor kunyit, inflasi, luas lahan dan nilai tukar rupiah terhadap Dolar Amerika Serikat (USD). Untuk mengetahui pengaruh masing-masing variabel terhadap produksi kunyit menggunakan analisis regresi dengan rumus sebagi berikut :

$$
\begin{aligned}
\mathrm{Y}=\mathrm{a} & +\mathrm{b}_{1} \mathrm{X}_{1}+\mathrm{b}_{2} \mathrm{X}_{2}+\mathrm{b}_{3} \mathrm{X}_{3}+\mathrm{b}_{4} \mathrm{X}_{4}+\mathrm{b}_{5} \mathrm{X}_{5}+\mathrm{e} \\
\text { Keterangan : } & \\
\mathrm{Y} & =\text { jumlah produksi kunyit tahun 2002-2016 } \\
\mathrm{a} & =\text { konstanta } \\
\mathrm{b}_{1} & =\text { koefisien jumlah ekspor kunyit } \\
\mathrm{X}_{1} & =\text { jumlah ekspor kunyit tahun 2002-2016 } \\
\mathrm{b}_{2} & =\text { koefisien jumlah impor kunyit } \\
\mathrm{X}_{2} & =\text { jumlah impor kunyit tahun 2002-2016 } \\
\mathrm{b}_{3} & =\text { koefisien tingkat inflasi } \\
\mathrm{X}_{3} & =\text { tingkat inflasi tahun 2002-2016 } \\
\mathrm{b}_{4} & =\text { koefisien luas lahan } \\
\mathrm{X}_{4} & =\text { luas lahan tahun 2002-2016 } \\
\mathrm{b}_{5} & =\text { koefisien nilai tukar rupiah } \\
\mathrm{X}_{5} & =\text { nilai tukar rupiah 2002-2016 } \\
\mathrm{e} & =\text { error }
\end{aligned}
$$

Tujuan dari analisis regresi adalah untuk membuat prediksi nilai suatu variabel terikat berdasarkan nilai variabel bebas (Rachmad, 2012). Dalam penelitian ini yang merupakan variabel bebas yaitu jumlah produksi kunyit. Sedangkan variabel terikat terdiri dari jumlah ekspor kunyit, jumlah impor kunyit, tingkat inflasi, luas lahan dan nilai tukar rupiah. 


\section{HASIL DAN PEMBAHASAN}

\section{Produksi Kunyit di Indonesia}

Pembangunan pertanian terutama di bidang tanaman obat sangat dipengaruhi oleh peran serta masyarakat. Ketertarikan masyarakat dalam bidang pertanian sangat dipengaruhi oleh prospek dari tanaman yang diusahakan. Semakin bagus prospek tanaman tersebut, maka masyarakat akan berbondong-bondong untuk membudidayakan. Kunyit merupakan salah satu tanaman yang memiliki prospek yang bagus. Kebutuhan kunyit dimasyarakat cukup tinggi, karena selain untuk bumbu dapur juga digunakan untuk memenuhi industri-industri obat tradisional. Dengan semakin banyak masyarakat yang berperan serta mengembangkan kunyit diharapakan dapat meningkatkan produksi tanaman tersebut.

Table 1. Production and Productivity of Turmeric in Indonesia in 2002-2016

\begin{tabular}{cccc}
\hline Tahun & Produksi $(\mathrm{kg})$ & Luas Lahan $\left(\mathrm{m}^{2}\right)$ & Produktivitas $\left(\mathrm{kg} / \mathrm{m}^{2}\right)$ \\
\hline 2002 & 23.993 .017 & 16.840 .783 .00 & 1,42 \\
2003 & 30.707 .451 & 18.942 .114 & 1,62 \\
2004 & 40.467 .232 & 24.571 .671 & 1,65 \\
2005 & 82.107 .401 & 48.372 .705 & 1,78 \\
2006 & 112.900 .000 & 53.805 .760 & 2,09 \\
2007 & 117.500 .000 & 58.901 .389 & 2,7 \\
2008 & 111.300 .000 & 59.092 .996 & 2,06 \\
2009 & 124.000 .000 & 54.544 .926 & 2,18 \\
2010 & 107.400 .000 & 45.580 .703 & 2,21 \\
2011 & 84.803 .466 & 39.537 .704 & 2,03 \\
2012 & 96.979 .119 & 46.995 .865 & 1,96 \\
2013 & 120.726 .111 & 54.285 .554 & 2,22 \\
2014 & 112.088 .181 & 50.464 .523 & 2,22 \\
2015 & 113.101 .185 & 56.578 .610 & 1,99 \\
2016 & 107.770 .473 & 51.709 .670 & 2,08 \\
\hline
\end{tabular}

Sumber : Kementerian Pertanian, 2015; Badan Pusat Statistik, 2016

Berdasarkan Table 1, hasil produksi kunyit di Indonesia mengalami pasang surut. Produksi terendah terlihat di tahun 2002 yaitu sebesar $23.993 .017 \mathrm{~kg}$. Jumlah tersebut terus mengalami kenaikan namun pada tahun 2008 sempat mengalami sedikit penurunan. Pada tahun 2009 terlihat bahwa produksi kunyit berada pada posisi tertinggi. Namun, pada tahun berikutnya kembali mengalami penurunan. Tinggi rendahnya produksi kunyit tidak selalu sebanding dengan tinggi rendahnya produktivitas.

Tinggi rendahnya produktivitas selain dipengaruhi oleh jumlah produksi juga dipengaruhi luas lahan yang ada. Berdasarkan Table 1. produktivitas tertinggi dicapai pada tahun 2007 dengan total produktivitas $2,7 \mathrm{~kg} / \mathrm{m}^{2}$. Kenaikan produksi sejalan dengan bertambahnya luas lahan yang digunakan untuk budidaya kunyit. Luas lahan terus bertahan dari tahun ke tahun namun pada tahun 2009 mengalami penurunan, namun penurunan lahan tidak diikuti dengan penurunan produktivitas. Luasan lahan kembali bertambah di tahun 2012 namun produktivitas mengalami penurunan. Pada tahun 2013 luas lahan dan jumlah produksi mengalami kenaikan yang signifikan namun pada tahun 2014 kembali mengalami penurunan.

Menurut Makruf et al. (2012), faktor yang mempengaruhi produktivitas yaitu luas lahan, jumlah pupuk, jumlah tenaga kerja, jumlah pestisida, dan jumlah benih. Sedangkan menurut Sesbany (2011), faktor yang paling berpengaruh terhadap produktivitas yaitu varietas tanaman yang digunakan, jarak tanam dan populasi tanaman. Sedangkan menurut Thamrin (2014), faktor yang paling berpengaruh yaitu besarnya penggunaan pupuk dan faktor tenaga kerja.

\section{Nilai Ekspor dan Impor Kunyit di Indonesia}

Perdagangan (ekspor dan impor) merupakan salah satu kunci dari pertumbuhan ekonomi suatu negara disamping konsumsi, investasi, dan pengeluaran pemerintah. Secara historis, pertumbuhan ekonomi di negara-negara maju sangat didukung oleh pertumbuhan ekspor sehingga negara tersebut menguasai pangsa 
ekspor dunia. Sejalan dengan hal tersebut, pemerintah Indonesia juga menempatkan ekspor sebagai salah satu lokomotif pertumbuhan ekonomi Indonesia. Agar target ekspor tersebut dapat dievaluasi dan sekaligus untuk merumuskan upaya-upaya antisipasi, maka perlu dilakukan identifikasi faktor-faktor yang mempengaruhi ekspor Indonesia. Faktor tersebut secara garis besar dapat dibagi menjadi faktor domestik dan faktor pasar internasional. Faktor domestik antara lain mencakup kapasitas produksi, harga di pasar domestik dan berbagai kebijakan domestik. Disisi lain, faktor yang bersumber dari pasar internasional antara lain mencakup harga pasar internasional, nilai tukar, dan sisi permintaan dari negara importir produk Indonesia. Sisi permintaan negara importir antara lain kondisi pertumbuhan ekonomi, produk pesaing, serta kebijakan terkait di negara importir (Lubis, 2013).

Table 2. Number of Turmeric Exports and Imports in Indonesia in 2002-2016

\begin{tabular}{ccc}
\hline Tahun & Ekspor $(\mathrm{kg})$ & Impor $(\mathrm{kg})$ \\
\hline 2002 & 40.753 & 16.680 \\
2003 & 135.743 & 4.963 \\
2004 & 206.764 & 1.132 \\
2005 & 1.329 .863 & 2.881 \\
2006 & 2.646 .818 & 951 \\
2007 & 1.182 .013 & 94.616 \\
2008 & 987.540 & 72.296 \\
2009 & 2.664 .656 & 59.998 \\
2010 & 6.118 .557 & 21.712 \\
2011 & 2.672 .115 & 269.541 \\
2012 & 1.212 .312 & 119.373 \\
2013 & 249.491 & 475.280 \\
2014 & 225.413 & 291.984 \\
2015 & 152.966 & 299.930 \\
2016 & 275.309 & 411.984 \\
\hline
\end{tabular}

Sumber: Badan Pusat Statistik, 2017, 2018; Kementerian Pertanian, 2015

Jumlah ekspor dan impor kunyit di Indonesia sangat fluktuatif (Table 2). Ekspor tertinggi terjadi pada tahun 2010 yaitu sebesar 6.118 .557 $\mathrm{kg}$ sedangkan ekspor terendah terjadi pada tahun 2002 yaitu sebesar $40.753 \mathrm{~kg}$. Jumlah impor tertinggi terjadi pada tahun 2013 yaitu sebesar $475.280 \mathrm{~kg}$ dan terendah pada tahun 2006 yaitu sebesar $951 \mathrm{~kg}$. Berdasarkan data ekspor dan impor kunyit (Table 2), kenaikan jumlah ekspor kunyit tidak mampu menurunkan jumlah impor kunyit di Indonesia. Menurut Rahmanda (2017), impor dan ekspor dilakukan pada saat yang bersamaan disebabkan oleh kendala teknis komoditas yang tidak sesuai untuk mencukupi kebutuhan domestik. Sehingga komoditas tersebut harus diekspor ke luar negeri dan selanjutnya akan diimpor kembali ke Indonesia dalam bentuk olahan yang lain.

\section{Nilai Inflasi di Indonesia}

Menurut data Bank Indonesia (2018), inflasi diartikan sebagai kenaikan harga secara umum dan terus menerus dalam jangka waktu tertentu. Inflasi yang terjadi di Indonesia selama kurun waktu 2002-2016 dapat dilihat pada Table 3.

Table 3. Inflation Value in Indonesia in 2002-

\begin{tabular}{cc}
2016 & \\
\hline Tahun & Inflasi (\%) \\
\hline 2002 & 10,03 \\
2003 & 5,06 \\
2004 & 6,40 \\
2005 & 17,11 \\
2006 & 6,60 \\
2007 & 7,36 \\
2008 & 5,47 \\
2009 & 2,78 \\
2010 & 6,96 \\
2011 & 3,79 \\
2012 & 4,30 \\
2013 & 8,38 \\
2014 & 8,36 \\
2015 & 3,35 \\
2016 & 3,02 \\
\hline
\end{tabular}

Sumber : Bank Indonesia, 2018

Berdasarkan Table 3, inflasi tertinggi terjadi pada tahun 2005 yaitu sebesar 17,11\% sedangkan inflasi terendah terjadi pada tahun 2009 yaitu sebesar $2,78 \%$. Jika harga barang dan jasa di dalam negeri meningkat, maka inflasi mengalami kenaikan. Naiknya harga barang dan jasa tersebut menyebabkan turunnya nilai uang. Dengan demikian, inflasi dapat juga diartikan sebagai penurunan nilai uang terhadap nilai barang dan jasa secara umum. 
Nilai Tukar Rupiah terhadap Dolar Amerika Serikat

Table 4. Rupiah Exchange Rate (IDR) against United States Dollar (USD) / 1, year 2002-2016

\begin{tabular}{|c|c|}
\hline Tahun & Nilai Tukar (dalam IDR) \\
\hline 2002 & 9.261 \\
\hline 2003 & 8.571 \\
\hline 2004 & 9.030 \\
\hline 2005 & 8.909 \\
\hline 2006 & 9.141 \\
\hline 2007 & 9.142 \\
\hline 2008 & 9.771 \\
\hline 2009 & 10.356 \\
\hline 2010 & 9.078 \\
\hline 2011 & 8.873 \\
\hline 2012 & 9.418 \\
\hline 2013 & 10.562 \\
\hline 2014 & 11.884 \\
\hline 2015 & 13.457 \\
\hline 2016 & 13.329 \\
\hline
\end{tabular}

Nilai tukar mata uang atau yang sering disebut dengan kurs adalah harga satu unit mata uang asing dalam mata uang domestik atau dapat juga dikatakan harga mata uang domestik terhadap mata uang asing (Simorangkir dan Suseno, 2004). Berdasarkan Table 4. nilai tukar rupiah terhadap dolar Amerika Serikat mengalami fluktuasi. Pada tahun 2009 nilai tukar rupiah melemah terhadap dolar Amerika Serikat. Kemudian tahun 2010 rupiah kembali menguat, namun sejak tahun 2012 nilai tukar rupiah kembali melemah.

\section{Nilai Uji Regresi}

Berdasarkan hasil analisis diperoleh nilai koefisien korelasi sebesar 0,998. Hal ini berarti bahwa antara variabel bebas secara bersama-sama mempunyai hubungan yang kuat dengan variabel terikat (produksi kunyit). Suatu variabel mempunyai hubungan yang kuat ditunjukkan dengan nilai $r \geq 0,5$ (Rachmad, 2012). Sedangkan hasil analisis koefisien determinasi diperoleh nilai $\mathrm{R}^{2}$ sebesar 0,997. Artinya variabel produksi terikat mampu menjelaskan variabel ekspor terikat sebesar $99,7 \%$ dan sisanya yaitu sebesar $0,3 \%$ dijelaskan oleh faktor lain.

Table 5. Regression Test Results Factors Affecting Turmeric Production

\begin{tabular}{lccc}
\hline & Koefisien Regresi & t hitung & Signifikansi \\
\hline Konstanta & $-1,315$ & $-1,293$ & $0,228^{\text {ns }}$ \\
X1 (ekspor) & 4,129 & 6,518 & $0,000^{*}$ \\
X2 (impor) & 6,167 & 0,721 & $0,489^{\text {ns }}$ \\
X3 (inflasi) & $-1,061$ & $-3,839$ & $0,004^{*}$ \\
X4 (luas lahan) & 2,058 & 33,654 & $0,000^{*}$ \\
X5 (nilai tukar rupiah) & 1139,22 & 1,36 & $0,207^{\text {ns }}$ \\
R & 0,998 & & \\
$\mathrm{R}^{2}$ & 0,997 & & \\
\hline
\end{tabular}

Keterangan: * $=$ berpengaruh nyata

ns $=$ tidak berpengaruh nyata

Berdasarkan hasil analisis Table 5. dapat dibuat persamaan regresi sebagai berikut :

$\mathrm{Y}=-1,315+4,129 \mathrm{X}_{1}+6,167 \mathrm{X}_{2}-1,061 \mathrm{X}_{3}+$ $2,058 \mathrm{X}_{4}+1139,22 \mathrm{X}_{5}$

Table 6. Rupiah Exchange Rate (IDR) against United States Dollar (USD) / 1, year 2002-2016

\begin{tabular}{llll}
\hline & Df & Fhitung & Signifikansi \\
\hline Regesi & 5 & 513.598 & $.000^{*}$ \\
Residual & 9 & & \\
Total & 14 & & \\
\hline
\end{tabular}

Keterangan : $*$ = berpengaruh nyata
Berdasarkan Table 5 dan Table 6, seluruh variabel secara bersama-sama berpengaruh nyata terhadap produksi kunyit di Indonesia. Sedangkan secara parsial hanya tiga variabel yang berpengaruh nyata terhadap produksi, yaitu ekspor, luas lahan dan inflasi.

Produksi kunyit di Indonesia dipengaruhi oleh ekspor. Meningkatnya permintaan dari luar mengakibatkan petani untuk berbondongbondong membudidayakan kunyit. Semakin bertambahnya minat petani yang membudidayakan kunyit atau bertambahnya luas lahan budidaya kunyit akan meningkatkan volume produksi. Dengan bertambahnya volume 
produksi maka kebutuhan dalam negeri akan terpenuhi dan sisa produksi dapat diekspor. Menurut Anshari et al. (2017), tingkat inflasi dan nilai tukar mata uang berpengaruh secara signifikan terhadap ekspor. Sedangkan berdasarkan penelitian Putra dan Sutrisna (2017), tingkat inflasi tidak berpengaruh langsung terhadap ekspor.

Berdasarkan penelitian Wibowo (2013); Zaeroni dan Rustariyuni (2016), kenaikan dan penurunan nilai ekspor secara tidak langsung mempunyai pengaruh terhadap produksi. Penurunan nilai ekspor menyebabkan terjadinya penurunan jumlah tenaga kerja yang bekerja di sektor pertanian. Penurunan jumlah tenaga kerja akan menurunkan jumlah produksi. Sebaliknya, kenaikan nilai ekspor akan meningkatkan jumlah kebutuhan tenaga kerja serta akan meningkatkan volume produksi.

Nilai tukar mata uang mempengaruhi nilai ekspor (Ginting, 2013; Wardani dan Sudirman, 2014; Fajar et al., 2017). Acuan dalam perdagangan dunia umumnya menggunakan mata uang Dolar Amerika Serikat (USD). Ketika nilai dolar naik biasanya minat eksportir untuk menjual barang keluar negeri akan naik. Sebaliknya ketika nilai dolar turun maka minat eksportir untuk menjual barang keluar negeri ikut turun. Faktor lain yang berpengaruh yaitu pertumbuhan ekonomi. Ketika pertumbuhan ekonomi suatu negara membaik, kecenderungan ekspor juga akan turut meningkat. Sebaliknya ketika pertumbuhan ekonomi terpuruk nilai ekspor juga akan menurun. Berdasarkan persamaan regresi, ketika terjadi kenaikan ekspor maka akan diikuti dengan kenaikan produksi.

Berdasarkan penelitian Pamungkas (2013), bahwa semakin meningkatnya impor mengakibatkan menurunnya produksi dan berdampak pada harga komoditas lokal yang meningkat. Terjadinya impor karena adanya pola konsumsi yang terus-menerus serta semakin meningkatnya impor ternyata juga diikuti dengan meningkatnya konsumsi di masyarakat. Sedangkan berdasarkan penelitian Utomo (2012), ekspor dan impor berpengaruh terhadap produksi.

Tingkat inflasi yang terjadi juga berpengaruh nyata terhadap produksi. Variabel inflasi mempunyai koefisien negatif, artinya ketika terjadi peningkatan inflasi maka produksi akan turun. Inflasi berkaitan erat dengan nilai tukar petani. Berdasarkan penelitian Faridah dan Syechalad (2016), bahwa inflasi berpengaruh negatif signifikan terhadap nilai tukar petani. Sedangkan berdasarkan penelitian Retnasari, (2015), jika nilai tukar petani meningkat maka akan terjadi inflasi.

Luas lahan berpengaruh nyata terhadap produksi. Hal ini sesuai dengan penelitian yang dilakukan oleh Fitri et al. (2015), yang menyatakan bahwa luas lahan berpengaruh nyata terhadap produksi padi di Propinsi Aceh. Hal ini semakin diperkuat dengan hasil penelitian Fadwiwati dan Tahir (2013) yang menyatakan bahwa luas lahan berpengaruh nyata terhadap produksi jagung. Semakin luas lahan yang digunakan untuk budidaya akan meningkatkan jumlah komoditas yang dihasilkan.

Ditinjau dari sisi budidaya, naungan tidak berpengaruh terhadap berat segar dan berat kering tanaman. Naungan menurunkan panjang akar, berat segar dan kering rimpang. Cekaman kekeringan tidak berpengaruh terhadap pertumbuhan dan hasil produksi kunyit (Ratri et al., 2015). Sedangkan hasil penelitian Samanhudi et al. (2018) menunjukkan bahwa aplikasi pupuk kandang ayam berpengaruh terhadap jumlah daun, jumlah anakan, dan bobot segar rimpang kunyit. Penambahan kotoran (ayam, kambing, sapi) dapat meningkatkan semua variabel pertumbuhan tanam yang meliputi tinggi tanaman, jumlah daun, jumlah anakan, bobot segar tanaman, berat kering tanaman, dan bobot segar rimpang.

\section{KESIMPULAN}

Berdasarkan hasil penelitian dapat disimpulkan bahwa variabel ekspor, impor, inflasi, luas lahan dan nilai tukar secara bersamasama berpengaruh secara signifikan terhadap produksi kunyit. Secara parsial, variabel ekspor, inflasi dan luas lahan berpengaruh secara signifikan terhadap produksi kunyit. Sedangkan variabel impor dan nilai tukar tidak memberikan pengaruh yang signifikan terhadap produksi kunyit.

\section{DAFTAR PUSTAKA}

Ahmad, W., Hasan, A., Abdullah, A., \& Tarannum, T. 2010. Curcuma longa, Linn - A Review. Hippocratic Journal of Unani Medicine, 5(4), 179-190. Retrieved from https://www.researchgate.net/publication/215 519165_Curcuma_longa_Linn_-_A_Review 
Anshari, M. F., Khilla, A. El, \& Permata, I. R. 2017. Analisis Pengaruh Inflasi dan Kurs Terhadap Ekspor di Negara Asean 5 Periode Tahun 2012-2016. INFO ARTHA, 1(2), 121. https://doi.org/10.31092/jia.v1i2.130

Badan Pusat Statistik, [BPS]. 2016. Statistik Tanaman Biofarmaka Indonesia 2016. Retrieved September 22, 2018, from https://www.bps.go.id/publication/2017/10/02 /1680a8fab1c2d22f1e359b34/statistiktanaman-biofarmaka-indonesia-2016.html

Badan Pusat Statistik, [BPS]. 2017. Statistik Perdagangan Luar Negeri Indonesia Impor 2016 Jilid III. Retrieved September 22, 2018, from

https://www.bps.go.id/publication/2017/06/05 /c32a5371b0b88593fda33e89/statistikperdagangan-luar-negeri-indonesia-impor2016-jilid-iii.html

Badan Pusat Statistik, [BPS]. 2018. Statistik Perdagangan Luar Negeri Indonesia Ekspor Menurut Kode ISIC 2016-2017. Retrieved September 22, 2018, from https://www.bps.go.id/publication/2018/07/02 /e8383056b240ee274ff4113c/statistikperdagangan-luar-negeri-indonesia-ekspormenurut-kode-isic-2016----2017.html

Bank Indonesia, [BI]. 2018. LAPORAN INFLASI (Indeks Harga Konsumen). Retrieved September 22, 2018, from https://www.bi.go.id/id/moneter/inflasi/data/ Default.aspx

Dinas Pertanian Daerah Istimewa Yogyakarta. (n.d.). Kunyit (Curcuma domestica Val). Retrieved September 21, 2018, from http://distan.jogjaprov.go.id/wpcontent/download/tanaman_obat/kunyit.pdf

Fadwiwati, A. Y., \& Tahir, A. G. 2013. Analisis Faktor-Faktor yang Mempengaruhi Produksi dan Pendapatan Usahatani Jagung di Provinsi Gorontalo. Jurnal Pengkajian Dan Pengembangan Teknologi Pertanian, 16(2), 92-101. Retrieved from http://ejurnal.litbang.pertanian.go.id/index.ph p/jpengkajian/article/view/4757

Fajar, F., Hakim, D. B., \& Rachmina, D. 2017. Hubungan Nilai Tukar terhadap Kegiatan Ekspor Manufaktur Pertanian Indonesia. Jurnal Aplikasi Bisnis Dan Manajemen, 3(2),
266-277.

https://doi.org/10.17358/jabm.3.2.266

Faridah, N., \& Syechalad, M. N. 2016. Analisis Faktor-Faktor yang Mempengaruhi Nilai Tukar Petani Sub Sektor Tanaman Pangan Padi di Aceh. Jurnal Ilmiah Mahasiswa Ekonomi Pembangunan, 1(1), 169-176. Retrieved from http://jim.unsyiah.ac.id/EKP/article/view/689

Fitri, N., Syechalad, M. N., \& Syahnur, S. 2015. Analisis Faktor-Faktor Yang Mempengaruhi Produksi Nelayan Di Kabupaten Aceh Timur. Jurnal Ilmu Ekonomi Pascasarjana Universitas Syiah Kuala, 3(1), 81-95. http://dx.doi.org/10.21082/jtidp.v4n2.2013.p1 65-174

Ginting, A. M. 2013. Pengaruh Nilai Tukar Terhadap Ekspor Indonesia (The Influence of Exchange Rate on Indonesia' $s$ Exports). Buletin Ilmiah Litbang Perdagangan, 7(1), 118. Retrieved from http://www.kemendag.go.id/files/pdf/2014/04 /08/-1396957338.pdf

Hartati, S. yuni. 2013. Khasiat Kunyit Sebagai Obat Tradisional dan Manfaat Lainnya. Warta Penelitian Dan Pengembangan Tanaman Industri, 5-9. Retrieved from http://perkebunan.litbang.pertanian.go.id/wpcontent/uploads/2014/02/Perkebunan_Khasiat Kunyit.pdf\%0A

Jurenka, J. S. 2009. Anti-inflammatory properties of curcumin, a major constituent of Curcuma longa: a review of preclinical and clinical research. Alternative Medicine Review: A Journal of Clinical Therapeutic, 14(2), 141153. Retrieved from http://www.ncbi.nlm.nih.gov/pubmed/195942 23

Kementerian Perdagangan Republik Indonesia. 2018. Nilai Tukar Mata Uang Asing Terhadap Rupiah. Retrieved September 22, 2018, from http://www.kemendag.go.id/id/economicprofile/economic-indicators/exchange-rates

Kementerian Pertanian, [Kementan]. 2015. Basis Data Statistik Pertanian. Retrieved September 22, 2018, from https://data.go.id/dataset/basisdata-statistik-pertanian

Krup, V., Prakash L, H., \& Harini, A. 2013. Pharmacological Activities of Turmeric 
(Curcuma longa linn): A Review. Journal of Homeopathy \& Ayurvedic Medicine, 02(04), $1-4$. https://doi.org/10.4172/21671206.1000133

Labban, L. 2014. Medicinal and pharmacological properties of Turmeric (Curcuma longa): A review. International Journal of Pharmaceutical and Biomedical Research, 5(1), 17-23. Retrieved from http://www.academia.edu/download/4438971 9/propreidades_medicinais_farmacologicas.p df

Lubis, A. D. 2013. Analisis Faktor Yang Mempengaruhi Kinerja Ekspor Indonesia. Retrieved from http://www.kemendag.go.id/files/pdf/2013/04 /25/-1366874912.pdf

Makruf, E., Oktavia, Y., \& Putra, W. E. 2012. Faktor-Faktor Yang Mempengaruhi Produksi Padi Sawah Di Kabupaten Seluma (Studi Kasus: Produktivitas Padi Sawah di Desa Bukit Peninjauan II Kecamatan Sukaraja). In PROSIDING SEMINAR INOVASI TEKNOLOGI PERTANIAN SPESIFIK LOKASI MENDUKUNG EMPAT SUKSES KEMENTERIAN PERTANIAN DI PROVINSI BENGKULU (pp. 44-52). Bengkulu: Balai Pengkajian Teknologi Pertanian (BPTP) Bengkulu, Badan Penelitian Dan Pengembangan Pertanian Kementerian Pertanian. Retrieved from https://www.researchgate.net/profile/Danner_ Sagala/publication/307012207_Perlakuan_nit rogen_dan_silikat_pada_persemaian_untuk_p ercepatan_pemulihan_pasca_terendam_dan_p eningkatan_produksi_padi/links/57c1298908a eda1 ec38a5859/Perlakuan-nitrogen-dansilikat-p

Nuroho, R. A., \& Ningsih, E. A. 2017. Produksi Tanaman Obat dalam Info Komoditi Tanaman Obat. (Z. Salim \& E. Munadi, Eds.) (September). Jakarta: Badan Pengkajian dan Pengembangan Perdagangan Kementerian Perdagangan Republik Indonesia. Retrieved from

http://bppp.kemendag.go.id/media_content/20 17/12/Isi_BRIK_Tanaman_Obat.pdf

Pamungkas, A. R. 2013. Pengaruh produksi, konsumsi dan harga terhadap impor bawang merah di kabupaten brebes tahun (2006.01 -
2010.12). Universitas Negeri Semarang. Retrieved from http://lib.unnes.ac.id/18210/1/7450406549.pd f\% $\% \mathrm{~A}$

Putra, G. N. A., \& Sutrisna, I. K. 2017. Pengaruh Produksi Dan Inflasi Terhadap Ekspor Dan Pertumbuhan Ekonomi Di Indonesia. E-Jurnal Ekonomi Pembangunan Universitas Udayana, 6(11), 2103-2351. Retrieved from https://ojs.unud.ac.id/index.php/eep/article/vie w/34943

Rachmad, M. 2012. Buku Ajar Biostatistika: Aplikasi pada Penelitian Kesehatan. Jakarta: Penerbit Buku Kedokteran EGC.

Rahmanda, M. T. 2017. Kenapa Indonesia Ekspor dan Impor Minyak Secara Bersamaan? Sebuah Penjelasan Sederhana - Dewan Energi Mahasiswa UGM. Retrieved from http://dem.ukm.ugm.ac.id/2017/05/27/kenapa -indonesia-ekspor-dan-impor-minyak-secarabersamaan/

Ratri, A. D. Y. S., Pujiasmanto, B., \& Yunus, A. 2015. Efek Naungan Dan Cekaman Air Terhadap Pertumbuhan Dan Hasil Kunyit Di Kismantoro, Wonogiri. Caraka Tani: Journal of Sustainable Agriculture, 30(1), 1-6. https://doi.org/10.20961/carakatani.v30i1.118 26

Retnasari, D. E. 2015. Pengaruh Nilai Tukar Petani Dan Pertumbuhan Ekonomi Terhadap Indeks Pembangunan Manusia Di Provinsi Jawa Timur. Jurnal Pendidikan Ekonomi (JUPE), 3(3). Retrieved from http://jurnalmahasiswa.unesa.ac.id/index.php/ jupe/article/view/12545

Salim, Z., \& Munadi, E. 2017. Info Komoditi Tanaman Obat. Jakarta: Badan Pengkajian dan Pengembangan Perdagangan Kementerian Perdagangan Republik Indonesia.

Samanhudi, Yunus, A., \& Pujiasmanto, B. 2018. Budidaya Organik Kunyit pada Kluster Biofarmaka Kabupaten Karanganyar. Caraka Tani: Journal of Sustainable Agriculture, $33(1)$, 34-41. https://doi.org/10.20961/carakatani.v33i1.191 12

Sesbany. 2011. Analisis Faktor-faktor Yang Mempengaruhi Produktivitas Jagung Hibrida, 28-43.
Retrieved from 
https://www.stppmedan.ac.id/pdf/Jurnal Vol 5/3-Sesbany.pdf\%0A

Sholehah, D. N., Amrullah, A., \& Badami, K. 2016. Identifikasi Kadar dan Pengaruh Sifat Kimia Tanah terhadap Metabolit Sekunder Kunyit (Curcuma domestiva Val.) di Bangkalan. Rekayasa, 9(1), 61-66. Retrieved from

http://journal.trunojoyo.ac.id/rekayasa/article/ view/3336

Simanjuntak, P. 2012. Studi Kimia Dan Farmakologi Tanaman Kunyit (Curcuma longa L) Sebagai Tumbuhan Obat Serbaguna. AGRIUM: Jurnal Ilmu Pertanian, 17(2), 103107. Retrieved from http://jurnal.umsu.ac.id/index.php/agrium/arti cle/view/306

Simorangkir, I., \& Suseno. 2004. Sistem dan Kebijakan Nilai Tukar. Jakarta: PUSAT PENDIDIKAN DAN STUDI KEBANKSENTRALAN (PPSK) BANK INDONESIA. Retrieved from https://www.bi.go.id/id/publikasi/serikebanksentralan/Documents/12. Sistem dan Nilai kebijakan Nilai Tukar.pdf\%0A

Sukandarrumidi. 2012. Metodologi Penelitian Petunjuk Praktis Peneliti Pemula. Yogyakarta: Ghajah Mada University Press.

Thamrin, S. 2014. Faktor-Faktor Yang Mempengaruhi Produksi Usahatani Kopi Arabika Di Kabupaten Enrekang Sulawesi
Selatan. Agric, 26(1), 1-6. https://doi.org/10.24246/agric.2014.v26.i1.p16

Utomo, S. 2012. Dampak Impor Dan Ekspor Jagung Terhadap Produktivitas Jagung Di Indonesia. ETIKONOMI, 11(2), 158-179. https://doi.org/10.15408/etk.v11i2.1891

Wardani, N. W. G., \& Sudirman, W. 2014. Pengaruh Harga, Produksi, Luas Lahan dan Kurs Dollar Amerika Serikat Terhadap Volume Ekspor Teh Indonesia Serta Daya Saingnya Periode 2000-2012. E-Jurnal Ekonomi Pembangunan Universitas Udayana, 4(1), 1-11. Retrieved from https://ojs.unud.ac.id/index.php/eep/article/vie $\mathrm{w} / 10551$

Wibowo, T. 2013. Dampak penurunan ekspor terhadap penyerapan tenaga kerja. Buletin Ilmiah Litbang Perdagangan, 7(2), 171-192. Retrieved from http://jurnal.kemendag.go.id/index.php/bilp/ar ticle/view/112

Zaeroni, R., \& Rustariyuni, S. D. 2016. Pengaruh Produksi Beras, Konsumsi Beras Dan Cadangan Devisa Terhadap Impor Beras Di Indonesia. Pengaruh Produksi Beras, Konsumsi Beras Dan Cadangan Devisa Terhadap Impor Beras Di Indonesia, 6(9), 902-1010. Retrieved from https://ojs.unud.ac.id/index.php/eep/article/vie w/23376 